Результативність навчально-пізнавальної діяльності студентів залежить не тільки від змісту, форм та методів навчання, але й самоконтролю за якістю отриманих спеціальних знань, умінь та навичок.

Традиційно у студентів сформувалось розуміння, що контроль виконує тільки викладач, і значно меншою мірою вони ознайомлені з такою формою, як самоконтроль. Тому формування у майбутніх учителів навичок самоконтролю у різних формах (перевірка самостійно виконаних робіт, розв'язання обраних практичних тестів, самостійне користування технічними приладами і методичними засобами навчання) $є$ ефективним способом розумового та морального становлення студентів.

\title{
Література
}

1. Каштальян И.А. Обработка на станках с числовым программным управлением / И. Каштальян, В. Клевзович. - К. : Высшая школа, 1989. - 271 с.

2. Мазеин П.Г. Виртуальные и реальные тренажеры с компьютерным управлением / П.Г. Мазеин, С.С. Панов, А.А. Беленов // Дистанционное и виртуальное обучение. - № 7. -2010 . C. $25-37$.

3. Мазеин П.Г. Развитие учебных комплексов с компьютерными системами числового программного управления / П.Г. Мазеин, С.В. Шереметьев, С.С. Панов, С.Н. Свиридов // Телекоммуникации и образование. - 2006. - №3. - С. 17-20.

4. Сосонкин В.Л. Программирование систем числового программного управления / В. Сосонкин, Г. Мартинов. - Логос, Университетская книга, 2008. - 344 с.

Стаття надійшла до редакції 30.05.2012 p.

\section{ШЛЯХИ ЕФЕКТИВНОГО ФОРМУВАННЯ ІНФОРМАЦЙНОЇ КУЛЬТУРИ МАЙБУТНІХ ІНЖЕНЕРІВ-ПЕДАГОГІВ В УМОВАХ МОДЕРНІЗАЦІЇ ВІТЧИЗНЯНОЇ ОСВІТНЬОЇ СИСТЕМИ}

\footnotetext{
Волкова Н.В. Шляхи ефективного формування інформаиійної культури майбутніх інженерів-педагогів в умовах модернізачії вітчизняної освітньої системи.

У статті розкрито шляхи ефективного формування інформаційної культури майбутніх інженерів-педагогів в умовах ВПНЗ. Доведено корелятивний взаємозв'язок між інформаиійним й технологічним аспектами формування інформаційної культури студентів у межах інформатизаиії вищої иколи. педагоги.

Ключові слова: інформачія, інформаційна культура, інформатизаиія, майбутні інженери-

Волкова Н. В. Пути эффективного формирования информащионной культуры будущих инженеров-педагогов в условиях модернизачии отечественной образовательной системьл.

В статье раскрыты пути эффективного формирования информационной культуры будущих инженеров-педагогов в условиях ВПУЗ. Доказана коррелятивная взаимосвязь между информачионным и технологическим аспектами формирования студентов информачионной культуры в рамках информатизачии высшей школье.

Ключевые слова: информация, информационная культура, информатизачия, будущие инженеры-педагоги.
} 
Volkova $N$. Ways effectiveness of information culture of the future engineers and educators in the modernization of the national education system.

In the article the way of effective information culture of the future engineers and educators in VPUZ. Proved correlative relationship between information and technological aspects of the formation of students' information culture within the higher education informatization.

Key words: information, information culture, information, future engineers, teachers.

Третє тисячоліття $\epsilon$ новітньою епохою нових інформаційних технологій. Збільшення потоку інформації в останні роки вимагає від людини формувати та розвивати такі інформаційні вміння: знаходити, обробляти, запам'ятовувати та використовувати інформацію. Щоб досягти зрілості, високої духовної культури, розвитку творчих здібностей, людині потрібні не лише знання, а й уміння самостійного пошуку інформації, вироблення вмінь та навичок самоосвіти. Інформаційні вміння $є$ основою для успішного засвоєння всіх навчальних предметів, надаючи можливість людині вільно орієнтуватися у потоці інформації.

3 другої половини XX століття людство перебуває на шляху здійснення соціотехнічної революції, результатом якої $\epsilon$ формування нового типу суспільного устрою - інформаційного суспільства. Безумовно, йдеться про час, що характеризується значним ростом обсягів інформаційних потоків як в економіці, управлінні, науці, соціальній сфері, так і в інших сферах життя. Відбувається зміна способів виробництва, світогляду людей,міждержавних відносин. Інформаційні технології набувають перспективно широке застосування, кардинально змінюючи повсякденне життя людей. Усвідомлення природи цих змін - необхідна передумова для розв'язання практично будьякого прикладного завдання. Держава набуває в інформаційному суспільстві нових рис, нового значення. В інформаційному суспільстві істотно підвищуються вимоги до рівня підготовки всіх його учасників. Викладене вище переконує в необхідності формування нового світогляду, переосмислення деяких цінностей, що розширює дискурс формування нового світогляду корелятивно до культури в умовах інформаційного суспільства.

Поняття інформаційної культури перебуває у полі посиленої уваги вітчизняних i зарубіжних науковців. Цінним для нашої розвідки $\epsilon$ дослідження А. Атаяна, який уважає, що інформаційна культура має трактуватися як розуміння ролі соціальної, наукової та інших видів інформації та інформаційного забезпечення як у професійній діяльності, так i в аспекті загальнолюдських, гуманістичних цінностей; уявлення про головні способи та напрями використання засобів інформатики, інформаційних технологій у розвитку суспільства [1].

Дослідники А. Органов та $\quad$ I. Хангельдиева під інформаційною культурою розуміють якісну характеристику життєдіяльності людини передовсім у сфері отримання, передавання, зберігання і використання інформації, де пріоритетними є загальнолюдські цінності [6].

Найбільш повне визначення, на нашу думку, надав український науковець В. Цимбалюк: «Інформаційна культура - це якісна оцінка за 
певними критеріями (умовами) рівня функціонування структурних одиниць суспільства (окремих індивідів, підрозділів та конкретної соціальної системи в цілому, як сфери суспільних відносин) щодо скеровування технологічного забезпечення отримання, передавання, зберігання і використання інформації щодо досягнення узгоджених і визначених нормативно у суспільстві цілей завдань» [11].

Розв'язання суперечностей, наявних у системі підготовки майбутніх фахівців у царині освіти, зумовлює доцільність спеціального дослідження, спрямованого на з'ясування сутності змісту, оптимальних методів і умов формування інформаційної культури студентів ВПНЗ.

Аналіз стану підготовки майбутніх інженерів у процесі навчання у вищому педагогічному навчальному закладі свідчить про наявність суперечностей: між творчою природою пізнавальної діяльності й переважно репродуктивними, відтворювальними формами навчання; між інтенсивними темпами зростання обсягів професійно значущої інформації і недостатньо ефективними способами піi усвідомлення й опанування; між інтелектуалізацією праці сучасного фахівця та невідповідністю рівня інформаційної компетентності студентів.

Специфіка викладання і вивчення профільних дисциплін у процесі фахової підготовки майбутніх інженерів відкриває значні можливості щодо розв'язання визначеної проблеми під час їх опанування у вищому навчальному закладі.

Мета публікації - окреслити шляхи ефективного формування інформаційної культури майбутніх інженерів в умовах ВПНЗ.

Грунтовний аналіз науковцями Т.Богдановою [3], А.Пеньковим [7], О. Ромашиною [8] поняття «інформаційна культура» показав, наскільки багатогранним і складним це є питання.

Комунікативно-діяльнісний підхід послідовно обгрунтовує А. Пеньков, звертаючи увагу на те, що «особливу увагу при формуванні інформаційної культури слід приділяти культурі спілкування - умінню обгрунтовано викладати свою точку зору, умінню вислуховувати іншу й давати їй об’єктивну оцінку, укладати програму спільної діяльності для досягнення спільної мети» [7, с. 41].

Використання персонального комп’ютера у процесі професійної підготовки відкриває перспективи якісного вдосконалення навчання на основі інтеграції навчальних дисциплін, інтенсифікації навчального процесу й гуманізації його на основі диференціації, професійної спрямованості та індивідуалізації навчання, надаючи студентові можливість обирати складність навчального матеріалу, його стильові особливості i навіть послідовність вивчення навчального курсу. Комп'ютерні технології уможливлюють успішне розв'язання навчальних і практичних завдань, навіть таких, які поставив сам студент, і при цьому пояснити студентові хід міркувань; з'являється можливість повністю «занурювати» майбутнього спеціаліста в найрізноманітніші соціальнопрофесійні ситуації та приймати найбільш обгрунтоване рішення. 
Питання формування інформаційної культури як основи інноваційного потенціалу фахівця, його інтелектуального й фізичного розвитку, Отже, виходить за рамки цих дисциплін і стає основою формування цілісної системи взаємопов'язаних і взаємодіючих дисциплін у процесі професійної підготовки, що висуває вимоги до формування комп'ютерної грамотності та інформаційної культури майбутніх інженерів в умовах ВПНЗ.

Зауважимо, що поряд із трансформацією понять «комп'ютерна грамотність» й «інформаційна культура» змінюються і традиційні вчительські вимоги до знань - «знати та відтворювати» - трансформуються у вимогу інфосфери - «уміння знайти інформацію». Ефективність пошуку інформації, враховуючи інтенсивність інформаційних потоків, стає визначальним чинником розвитку особистості, формування iï інформаційної культури, соціальної адаптованості.

Автоматизовані системи, зокрема навчальні, є ефективним засобом розширення, поглиблення й зміцнення знань та умінь у тій галузі, де спеціалізується фахівець. Використання цих систем сприяє розкриттю творчого потенціалу, пізнавальних здібностей, формуванню наукового світогляду, сучасних понять про культурні та загальнолюдські цінності.

Опанування новими інформаційними технологіями формує новаторські підходи майбутніх учителів до розв'язання професійних завдань, орієнтує в подальшій педагогічній діяльності, розвиває уміння об'єктивно оцінювати ситуації, виявляти діловитість, творчість, доводити свою позицію, розв'язувати нестандартні завдання.

Н. Макарова у своїй роботі зазначає, що інформаційна культура - це рівень досягнутого в розвитку інформаційного забезпечення людей, а також характеристика інформаційної сфери життєдіяльності людей, у якій можна відрізнити ступінь досягнутого, кількістю і якістю створеного, тенденція розвитку, ступінь прогнозування майбутнього [5].

Наведені трактування поняття «інформаційної культури» не розкривають вичерпно іiі сутнісних характеристик, тому потребують уточнення. Визначення сутності цього поняття непросте завдання. Але іiі своєчасне розв'язання дозволить уникнути крайнощів, примітивного ремісництва й снобістського професіоналізму. При цьому поняття повинне бути досить містким, конкурентним, щоб, маючи свій фундаментальний зміст, воно,водночас, підводило користувачів комп'ютеризованих систем до вибору адекватного оволодіння інформатикою на всьому життєвому циклі.

Поняття «інформаційна культура особистості» входить до більш широкого - «культура особистості», під якою розуміється система особистісних якостей (розуму, характеру, уяви, пам'яті), що усвідомлюються самим індивідом як цінності й цінуються в суспільстві. Більш вузьке за обсягом поняття «інформаційна культура особистості» ми визначаємо як здатність і потребу фахівця використати доступні інформаційні можливості для систематичного й усвідомленого пошуку нового знання, його інтерпретації й поширення. При цьому зміст педагогічного аспекту 
проблеми підвищення інформаційної культури студента полягає в пошуку шляхів і засобів поєднання роботи з формуванням навичок збору, зберігання, переробки, поширення інформації і пізнавальних, інтелектуальних якостей майбутніх фахівців.

Аналізуючи інформаційну культуру, В. Цимбалюк розкриває багатогранність цього поняття і розглядає його в різних площинах системи суспільних відносин. При цьому виокремлюючи за суб'єктивним критерієм: інформаційну культуру особи; корпоративну інформаційну культуру (різних соціальних організацій); інформаційну культуру суспільства і держави (у особі їх органів); інформаційну культуру цивілізацій.

За об'єктними організаційно-правовими критеріями як: сферу суспільних відносин; міжгалузевий інститут інформаційного права; синтетичну наукову дисципліну; навчальну дисципліну; організаційноуправлінську категорію [11, с. 31-36.]

Водночас слід звернути увагу на кореляцію окреслених шляхів формування інформаційної культури майбутніх інженерів із розроблюваними автоматизованими системами, зокрема навчальними, які $\epsilon$ ефективним засобом розширення, поглиблення й зміцнення знань та умінь у тій галузі, де спеціалізується фахівець. Використання цих систем сприяє розкриттю творчого потенціалу, пізнавальних здібностей, формуванню наукового світогляду, сучасних понять про культурні та загальнолюдські цінності.

Опанування новими інформаційними технологіями формує новаторські підходи майбутніх учителів до розв'язання професійних завдань, орієнтує в подальшій педагогічній діяльності, розвиває уміння об'єктивно оцінювати ситуації, виявляти діловитість, творчість, доводити свою позицію, розв'язувати нестандартні завдання.

У межах інформаційно-діяльнісного підходу до формування інформаційної культури майбутніх інженерів комунікація зумовлюе необхідність урахування принципів, сформульованих Р. Якобсоном, П. Лазарсфельдом та Г. Лассуелом: по-перше, джерело інформації (комунікатор) завжди пов'язано 3 тим, як подається інформація; по-друге, прокоментована інформація $є$ повідомленням, що може містити ціннісно-емоційні аспекти; по-третє, важливе значення в процесі передавання інформації має контекст повідомлення, який, створюючи певний фон, може або посилювати, або нівелювати зміст інформації; по-четверте, повне спотворення інформації відбувається через «перешкоди», «шуми», які можуть виникати, як наслідок, між джерелом інформації та комунікатором (наприклад, міміка); між повідомленням та реципієнтом. В Інтернет-мережі «шумом» найчастіше $\epsilon$ некорисною (непотрібна) інформація, яка на більшості Web-сторінок $є$ «перемішаною», що вимагає від користувача вміння та здатності відфільтровувати потрібну інформацію; по-п'яте, на сприйняття інформації може впливати бар'єр, зумовлений груповою приналежністю індивіда, частина інформації сприймається через «лідерів думки» (Л. Угрін) [10]. 
Необхідно підкреслити, що поняття «інформаційна культура» так само, як i поняття «культура», відбиває практично досягнутий рівень управлінської діяльності на даний момент часу.

У філософському розумінні інформаційну культуру розглядають як рівень досягнутих інформаційних зв'язків у людському суспільстві за період інформаційного спілкування людей, як характеристику інформаційної сфери життєдіяльності суспільства.

Ефективним шляхом формування інформаційної культури є розвиток технологічного компонента. Інформаційна культура тісно перебуває в тісних зв'язках із технологічною культурою в тій іiі частині, що стосується оперування інформацією з різних видів діяльності. Власне кажучи, вся сфера технології органічно пов'язана з інформаційною культурою вже в силу того, що сама технологія (як конкретний феномен) має інформаційну природу. Важливим $\epsilon$ не просте знання як таке, саме по собі, але й у не меншою мірою можливість його трансляції й практичне втілення за допомогою різних механізмів комунікації й соціальної пам'яті, а комунікативна функція невід'ємний атрибут інформації в суспільстві.

Доречно зазначено науковцями Ю. Зубовим та Н. Сляднєвою, що інформаційна культура - «це не набір елементарних знань, необхідних кожному студенту, щоб не заблукати в бібліотеці або комп'ютері. Інформаційна культура - це методика, методологія та світогляд суспільства епохи інформатизації» [10, с.72].

Аналізуючи факти оперування інформацією, підсумовуємо, що стосовно до технічного аспекту діяльності відомий оптимум інформаційної культури, об'єктивно необхідний у різних площинах i на різних етапах розгортання процесу. По-перше, при розробці технологій і їхньої супровідної документації (у тих галузях, де практикується іiі оформлення). По-друге, при сприйнятті такої документації, у якій відображена сукупність технологічних прийомів учасниками виробництва. По-третє, при реалізації цих технологій, їхньому втіленні в практичну діяльність.

Нарешті, коли виникають імпульси зворотного зв'язку з коректування в технології, у неї вносять відповідні зміни. У всіх таких ситуаціях тільки наявність необхідного рівня інформаційної культури здатна забезпечити успіх діяльності (зрозуміло, не можна сказати, що ця умова є достатньою, але до числа обов'язкових передумов вона, звичайно, входить).

Однак суть справи, як нам видається, полягає не в окремих етапах й операціях технологічного забезпечення виробництва всіх видів. Першочергового значення набуває той факт, що загальний рівень інформаційної культури одна 3 найважливіших детермінант інтелектуального клімату епохи й конкретного соціуму, а цей чинник завжди відіграє кардинальну й визначальну роль у технологічному прогресі суспільства.

Осмислення поняття інформаційної культури неможливе без урахування специфіки суспільного розвитку на конкретних етапах. Відповідно до цього дослідник Л. Скворцов аналізує останню як фундаментальний вимір життя 
сучасного постіндустріального суспільства, до суттєвих ознак якого зараховує: докорінну зміну структури зайнятості населення (понад 50\% тих, хто працює, задіяні у сфері виробництва послуг); зростання питомої ваги висококваліфікованого персоналу в усіх галузях виробництва й управління; провідну роль наукових досліджень у розвитку суспільства в цілому й виробництва зокрема [9].

Ми розглядаємо інформаційну культуру як складову професійної культури вчителів. Інформаційна культура, 3 одного боку, характеризує суб'єктів педагогічної діяльності, а 3 іншого - $є$ умовою ефективності цієї діяльності. Незважаючи на незвичне сполучення слів «інформаційна культура», цей термін закономірний i означає відповідну організацію процесу керування.

Один із шляхів ефективного формування інформаційної культури визначається необхідністю усвідомлення інформаційної культури як процесу творчої діяльності. Інформаційна культура аналізується крізь призму процесів духовного виробництва (виробництва духовних благ, цінностей, знань, інформації), функціонування та вдосконалення особи. Другий шлях визначається тим, що інформаційна культура розглядається як специфічний спосіб людської діяльності. Представники другого підходу (концепції) пропонують загальну модель культури як універсальної властивості суспільного життя.

Інформаційна культура є продуктом різноманітних творчих здібностей людини й виявляється в таких аспектах:

- конкретних навичках 3 використання технічних засобів (від арифмометра до персонального комп’ютера й комп’ютерних мереж);

- здатності використовувати у своїй діяльності комп'ютеризовану інформаційну технологію, базовою складовою якої є численні програмні продукти;

- умінні здобувати інформацію з різних джерел: як із періодичної преси, так і з електронних комунікацій, й умінні їі ефективно використовувати;

- оволодінні основами аналітичної переробки інформації;

- умінні працювати з різною інформацією;

- знанні особливостей інформаційних потоків у своїй галузі діяльності;

- використанні правових актів, що забезпечують інформаційні процеси;

- оволодінні основами ергономічної й інформаційної безпеки.

Окреслимо галузі науки й техніки, що мають безпосереднє відношення до інформаційної культури і які відповідно до цього $\epsilon$ елементами інформаційної культури і становлять шляхи іiі формування.

Інформаційна культура містить такі джерела (рис. 1):

- засоби масової інформації;

- друкарські засоби;

- нові інформаційні технології.

Структура інформаційної культури характеризує лише засоби інформації, але у змісті досліджуваного феномену виокремлюють комплекс правил, вимог до використання в практичній діяльності різних засобів інформації. 


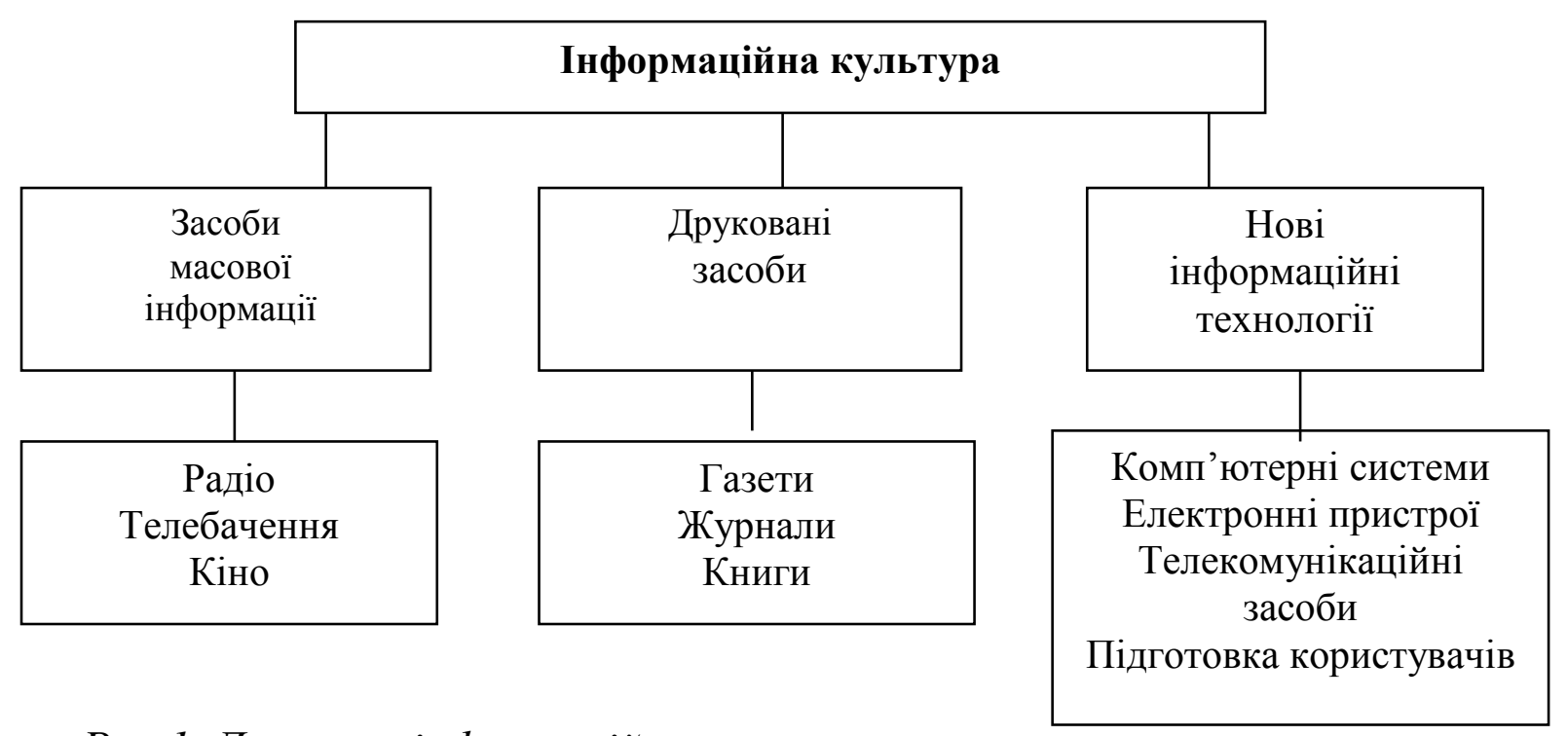

Рис.1. Джерела інформачійної культури

Кожна із складових інформаційної культури є багатогранним науковим поняттям. Центральне поняття, яке покладено в основу формування інформаційної культури, $є$ поняттям інформації. Системне вивчення складових інформації як об'єктивне відображення реального світу в знання i мислення людини в сучасній педагогічній науці $є$ панівним. Так, на думку Д. Блюменау, інформація «...це не речовина і не енергія, а продукт наукового пізнання, засіб вивчення реальної дійсності у межах допустимих методологій інформаційного підходу»[3].

У сучасних суспільствах ці пункти можуть найефективніше реалізуватися 3 використанням сукупності методів та засобів сучасних інформаційних технологій, насамперед, Інтернету. У такому сенсі, інформаційна культура це також культура поведінки зі знаннями, даними та інформацією, які зосереджені на комп'ютерах всесвітньої мережі Інтернет. Інформаційна культура також передбачає:

- комп'ютерну грамотність, теоретичні знання та навички роботи в Інтернеті (насамперед, навігаціï), а також знання нових інформаційних технологій, що постійно вдосконалюються (зокрема, програмного забезпечення для автоматизованої обробки та передачі інформації в реальному масштабі часу);

- знання конкретних послуг (сервісів Інтернету та вміння користуватися ними (електронна пошта, телеконференції, протокол передавання файлів, найпопулярніша послуга, яка за запитом користувача може надсилати на його комп'ютер документи 3 різною інформацією - WordWideWeb або WWW тощо). Сервіси Інтернету можна поділити на прямі послуги та послуги відкладеного читання. Останнє $є$ найбільш поширеним та універсальним і має найменші вимоги до ресурсів комп'ютера.

Інформаційна культура пов'язана також із процесами обміну інформації, що вимагає об'єктивних знань про комунікацію, тобто закономірності передавання та обміну інформації, іiі особливість у всесвітній мережі Інтернет. 
Отже, формування інформаційної культури майбутніх інженерів потребує цілісної багатокомпонентної системи роботи, спрямованої іiі на формування в студентів інтересу до роботи з інформацією та стійких потреб у застосуванні інформаційних технологій у професійній діяльності, розв'язанні різноманітних навчальних i життєвих питань, розумінні необхідності інформаційних знань, умінь, навичок і потреби їх постійного удосконалення на основі самоаналізу.

\section{Література}

1. Атаян А. Информационная культура. Проблемы формирования / А. Атаян //http://ito.edu.ru/1999///1/.

2. Блюменау Д.И. Информация и информационный сервис / Д.И. Блюменау. -Л.: Наука, 1968. - C. 9-21.

3.Богданова Т.Л. Формування інформаційної культури студентів технічних спеціальностей у вищих навчальних закладах : автореф. дис. на здобуття наук. ступеня канд. пед. наук : спец. 13.00.02 «Теорія та методика навчання (технічні дисципліни)» / Т.Л. Богданова. - Харків, 2007. - 27 с .

4. Информационная культура личности: прошлое, настоящее, будущее // Труды Международной научной конференции: тезисы докладов КГАК (Краснодар-Новороссийск, 11-16 сентября 1996г.). -Краснодар-Новороссийск, 1996. -490с.

5. Макарова Н.В. Программа по информатике и ИКТ. Системно-информационная концепция: базовый уровень / Н.В. Макарова.- СПб. : Питер, 2006. -288с.

6. Органов А.А. Теория культуры : [учеб. пособ. для вузов] / А.А. Органов, И.Г. Хангельдиева. - М. : ФАИР-ПРЕСС, 2001.

7. Пеньков А.В. Использование новой информационной технологии при преподавании математики в старших классах : дисс. канд. пед. наук: 13.00.09«Теорія навчання» / А.В.Пеньков. K., 1992. $-210 \mathrm{c}$.

8. Ромашина О.Я. Формування інформаційної культури студентів коледжів технічного профілю : автореф. дис. на здобуття наук. ступеня канд. пед. наук : спец. 13.00.04 «Теорія i методика професійної освіти» / О.Я. Ромашина. - Тернопіль, 2007. - 27 с.

9. Скворцов Л.В. Информационная культура и цельное знание: избранные труды/ Л.В. Скворцов. - Ин-т научн. нформ. по общественным наукам, 2001. $-228 \mathrm{c}$.

10.Угрин Л.Я. Формування інформаційної культури та розвиток громадянської освіти : (сесія третя) / Л.Я. Угрин // Internet [Електронний ресурс]. - 2004. - №12. - Назва з титул. екрану.

11. Цимбалюк В. Проблеми формування інституту інформаційної культури втеорії інформаційного права України / В. Цимбалюк // Правова інформатика. - 2003. - №1. - С. 31-36.

Стаття надійшла до редакції 30.05.2012 p.

УДК 378.147

Т. В. Яковенко,

кандидат пед. наук, доиент, Стахановський навчально-науковий інститут гірничих та освітніх технологій, Українська інженерно-педагогічна академія

\section{ДЕФІНІЦЙНИЙ АНАЛІЗ ПОНЯТТЯ «НАВЧАЛЬНЕ СЕРЕДОВИЩЕ ІНЖЕНЕРНО-ПЕДАГОГІЧНОГО ВНЗ»}

\footnotetext{
Яковенко Т.В.Дефініційний аналіз поняття «навчальне середовище інженернопедагогічного ВНЗ».

У статті узагальнено різні підходи до визначення понять «середовище», «освітнє середовище»; «навчальне середовище» представлено їх авторську інтерпретацію. На трунті аналізу наукових досліджень сформульовано дефінічію «навчальне середовище інженернопедагогічного ВНЗ».
} 